DOI https://doi.org/10.30525/978-9934-588-86-0.23

\title{
MEMORY EMERGENCE AS A FACTOR SHAPING THE SEAFARERS' SOLUTION OF CHOICE IN EMERGENCY SITUATION: THEORETICAL ASPECTS
}

\author{
Shevchenko R. P., Bondarevich S. M.
}

\section{INTRODUCTION}

Nowadays, the development of modern marine technology is focused on the increasing use of high-speed intelligent technologies, implementation of integrated systems of automatic ship process control, where the functions of the ship and its equipment control, previously performed by a man, are transferred to appliances and technical devices ${ }^{1}$.

The ongoing automation of ship navigation has significantly changed the conditions and nature of shipbuilders' work. Automation is aimed at improving the reliability and efficiency of equipment, increasing labor productivity, improving working conditions, reducing the number of crew, flight safety due to the human factor.

In ergonomics, human factors are understood as a combination of the anatomical, physiological, psychological and psychophysiological characteristics of a person, as well as the socio-psychological conditions that influence the efficiency of his life. An increase in the information load, a variety of tasks to be solved, and as a result an increase in the amount of responsibility, falls directly on the crew of the vessel, which often leads to the development of a situational stressful situation, which, in the absence of a decrease in stress, and by virtue of its duration, becomes stress chronic, and further, can lead to psychosomatic disorders ${ }^{2}$.

In the given conditions of work at sea, the data component of the work with high nervous and emotional tension, demanding the great attention and responsibility concentration, psychophysiological reserves mobilization, body adaptive capacities, ability to find the correct decision in time pressure of the

${ }^{1}$ Nikitina V. N., Lyashko G. G., Kalinina N. I. (2016) Osobennosti professionalnoy deyatelnosti moryakov na avtomatizirovannykh sudakh i zdorovye ekipazha [Features of the professional activities of sailors on automated vessels and crew health]. Profilakticheskaya meditsina: materialy Vserossiyskoy nauchno-prakticheskoy konferentsii s mezhdunarodnym uchastiyem (Russia, St. Petersburg, Noyabrya 15-16, 2016) (eds. A. V. Meltsera, I. S. Yakubovoy). SPb.: Izd-vo SZGMU im. I. I. Mechnikova, vol. 2, pp. 88-93 (in Russian).

${ }^{2}$ Zelenin M. P. (1999) Ergonomika na morskom transporte [Ergonomics in maritime transport], Odessa : BANTO (in Ukrainian). 
difficult and sometimes extreme situations based on the obtained skills and knowledge of the expert, or formation of qualitatively new emergent properties of memory becomes leading.

Any unusual psycho-emotional pressure may affect the psychophysiological state of a seafarer and impair his operational reserves, which is especially unfavourable in a maritime emergency.

Memory is a set of specific psychophysiological processes that allow capturing, storing and reproducing past experiences, in particular, the processes of professional learning ${ }^{3}$.

Therefore, the relevance of the research is conditioned both by the request of practice and the need to address the main tasks to be solved in the seafarer's training. This is the formation of the initial, sustainable, and restoration of sustainable, with bringing it to the automated professional skills, because the safety of modern navigation depends on the level of crew training.

The purpose of the paper is the data analysis of the scientific literature on properties of memory to get emergent properties in the process of learning and development of automatic behavior, necessary for the navigator when building qualitatively new professional skills.

Research Objectives: 1. To perform the analysis of the literature sources about the unfavorable factors of the seafarers' working conditions in the emergency situation at sea. 2. To analyze the connection between the psychophysiological memory parameter and the notion of emergence with the purpose of substantiation of its emergent properties as the main mechanism for a navigator when developing qualitatively new professional skills. 3. To reveal the possibility of getting emergent properties of memory on the basis of conditional reflexes and automatic behavior development for the purpose of increasing seafarers' proficiency and ship navigation safety.

Research methods. A set of complementary research methods has been used to solve the tasks and achieve the goal.

\section{DESCRIPTION OF CREW ADVERSE RISK FACTORS IN EMERGENCY SITUATION}

The analysis of literature sources has shown that navigation is inevitably associated with the effects of hazards that can lead to a loss of control, accident and even death ${ }^{4}$.

${ }^{3}$ Maltsev A. S., Golikova V. V. (2007) Dinamika psikhofiziologicheskikh funktsiy u kursantov i sudovoditeley pri reshenii zadach sudovozhdeniya na radiolokatsionnom trenazhere [Dynamics of psychophysiological functions among cadets and navigators in solving navigation problems on a radar simulator]. Aktualnyye problemy transportnoy meditsiny : sb. nauchn. trudov, Odessa : UkrNII meditsiny transporta. Vol. 1 (7), p. 20-26 (in Ukrainian). 
There is no such phenomenon or process that poses no danger to human activities at sea, in whole or in part. The sea itself, as an environment alien to natural habitat, is hostile to humans.

According to data, the emergency in maritime navigation is defined as the possibility of ships losing their state of navigation due to the influence of hazardous factors. This definition allows a quantitative assessment of the hazard degree, the measure of which is probability ${ }^{5}$.

The danger is characterized by the following symptoms: life threat; damage to health; difficulty in the functioning of human organs. However, according to the authors, the danger level (risk) can be controlled by the concept of acceptable risk. This concept is based on the fact that absolute security is unattainable and an understanding of this.

Human activities at sea already pose a danger to life at sea; the following types of dangers of navigation at sea exist: bottom topography and coastlines (shallows, reefs, rocks, banks, etc.); artificial fixed technical and floating structures (oil rigs, platforms, piers, bridges, oncoming vessels, etc.); hydrometeorological phenomena (dense fog, wind, current, storm waves, floating ice, icebergs, heavy snowfalls, downpours, low air temperatures, blizzards, hurricanes, tidal phenomena) are considered to be especially dangerous and extreme; floating uncontrollable objects (logs, trees, lost fishing equipment, buoys, barrels, etc., torn from anchors); failure of mechanisms, devices, structures; epidemics and other causes of physiological failure of crew members; improper placement of cargo, fuel, ballast, fishing equipment, etc., their unsatisfactory fastening; deliberate destructive or damaging effects on the ship and crew (military operations, piracy, crime) ${ }^{6}$.

The basis of the set of external production factors on the vessel, according to, is noise, vibration, high-frequency electromagnetic radiation, as well as the presence of harmful substances in indoor air, ship pitching, hydrodynamic shocks and other external influences.

${ }^{4}$ Kubasov R. V., Lupachev V. V., Popov M. V. (2016) Usloviya zhiznedeyatel'nosti ekipazha na bortu morskogo sudna (obzor literatury) [Conditions of crew life aboard a marine vessel (literature review)]. Vestnik Gosudarstvennogo universiteta morskogo $i$ rechnogo flota imeni admirala S. O. Makarova, no. 2(36), pp. 49-56.

${ }^{5}$ Kolegaev M. A., Ivanov B. N., Basanets N. G. (2007) Bezopasnost zhiznedeyatelnosti i vyzhivaniye na more: Ucheb posobiye [Life Safety and Survival at Sea: Textbook]. Pod red. V.V. Ponomarenko. Odessa : ONMA (in Ukrainian).

${ }^{6}$ Kubasov R. V., Lupachev V. V., Popov M. V. (2016) Usloviya zhiznedeyatel'nosti ekipazha na bortu morskogo sudna (obzor literatury) [Conditions of crew life aboard a marine vessel (literature review)]. Vestnik Gosudarstvennogo universiteta morskogo $i$ rechnogo flota imeni admirala S. O. Makarova, no. 2(36), pp. 49-56. 
Moreover, the exposure to the personnel of the vessel in relation to some factors occurs constantly (the microclimate of the premises, placement conditions, etc.), and others (temperature and electromagnetic radiation, the presence of harmful substances in the air) - periodically. One of the constant physical factors, which largely determines the health and performance of crew members, is the microclimate, which is determined, on the one hand, by navigation regions, and, on the other hand, by the quality of life support systems on board the vessel: heating, ventilation and air conditioning, cabins, the presence in them of technical devices that produce heat. The physical properties of air, causing the thermoregulation of the human body, are, first of all, a combination of temperature, humidity, air velocity. Toxic substances entering the air contain functionally active chemical groups that adversely affect the body of sailors, which manifests itself in the form of allergic reactions, skin and mucous membranes, poisoning, various neoplasms ${ }^{7,8}$.

Ship navigation automation, note, has significantly changed conditions and character of work of navigators 9 .

The implementation of modern automated management systems is followed by the crew reduction, due to which the process of combining professions and expanding the range of functional responsibilities of seafarers is underway.

The reduction in the number of crews increases the professional load on the average and junior composition of the vessel, and as a result, the responsibility for performing work tasks among the crew also increases, which often causes a stressful reaction with the subsequent development of prolonged stress.

As a result, with minimal staffing, the load on the crew increases, and as a consequence, the rapid fatigue growth, reduced concentration of attention and exhaustion, signs of "emotional burnout", against the background of changes in working and rest modes of the crew.

The authors believe that fatigue is directly associated with impaired performance, increased risk of chronic diseases and people's sensitivity to

\footnotetext{
${ }^{7}$ Rymina T. N., Pyatyrova Ye. V. (2014) Osobennosti vozdeystviya stressa na rabotnikov plavsostava $\mathrm{v}$ usloviyakh raboty $\mathrm{v}$ more [Features of the effects of stress on crew members in working conditions at sea]. Zdorovye. Meditsinskaya ekologiya. Nauka. vol. 4(58), pp. 103-105.

${ }^{8}$ Kolegaev M. A., Ivanov B. N., Basanets N. G. (2007) Bezopasnost zhiznedeyatelnosti i vyzhivaniye na more: Ucheb posobiye [Life Safety and Survival at Sea: Textbook]. Pod red. V.V. Ponomarenko. Odessa : ONMA (in Ukrainian).

${ }^{9}$ Vagushchenko L. L., Tsymbal N. N. (2002) Sistemy avtomaticheskogo upravleniya dvizheniyem sudna [Systems of automatic control of the movement of the vessel]. Odessa : Latstar (in Ukrainian).
} 
adverse factors, accelerated aging of the body, which in turn affects the safety of navigation ${ }^{10}$.

According to the data, long, frequent and rather strong stress at work is a usual phenomenon among the working vessels of the marine fleet. In fact, any work situation can become a potential source of stress ${ }^{11}$.

The work of the marine crew is connected with high personal and team responsibility, work tension as a characteristic of the specific work process, puts the main load on the central nervous system, senses, and emotional sphere of a person.

Works in studying specialties connected with professional hazard show that the greatest number of cases of cardiovascular diseases (CVD), arterial hypertension $(\mathrm{AH})$, gastric ulcer (GU) and duodenal ulcer are diagnosed among persons whose activity is connected with increased danger of work at sea $^{12,13}$.

The authors analyzed the data of outpatient records of seafarers during several years of observation based on the results of medical examinations and revealed that diseases related to the overstress of the central nervous system are registered in $80 \%$ of the command squad and only in $20 \%$ of other ship's crew members.

Studies on the role of stress and adaptive capacity of seafarers show that stressors are at the root of functional stress, physiological fatigue, and

10 Mamayenko YU.V., Chernenko Ye.V.(2010) Psikhofiziologicheskiye korrelyaty professionalnoy adaptatsii moryakov [Psychophysiological correlates of professional adaptation of sailors]. Aktualnyye problemy transportnoy meditsiny, no. 1 (19), pp. 31-36.

11 Rymina T. N., Pyatyrova Ye. V. (2014) Osobennosti vozdeystviya stressa na rabotnikov plavsostava $\mathrm{v}$ usloviyakh raboty $\mathrm{v}$ more [Features of the effects of stress on crew members in working conditions at sea]. Zdorovye. Meditsinskaya ekologiya. Nauka. vol. 4(58), pp. 103-105.

${ }^{12}$ Panov B. V., Balaban S. V., Cheban S. G., Samys'ko D. B., Lisobey V. A. (2013) Sostoyaniye zdorov'ya moryakov po rezul'tatam predvaritelnykh i periodicheskikh osmotrov. Soobshcheniye pervoye: mediko-statisticheskaya kharakteristika moryakov [The health status of seafarers according to the results of preliminary and periodic examinations. First message: medical and statistical characteristics of sailors]. Aktual'nyye problemy transportnoy meditsiny, no. 3(33), pp. 66-73.

${ }^{13}$ Panov B. V., Balaban S. V., Cheban S. G., Samys'ko D. B., Lisobey V. A. (2013) Sostoyaniye zdorov'ya moryakov po rezul'tatam predvaritel'nykh i periodicheskikh osmotrov. Soobshcheniye vtoroye: pokazateli zabolevayemosti moryakov raznykh vozrastnykh i stazhevykh grupp [The health status of seafarers according to the results of preliminary and periodic examinations. Second communication: morbidity indicators for sailors of different age and senior groups]. Aktualnyye problemy transportnoy meditsiny. no 3 (34), pp. 47-56 (in Ukrainian). 
professional burnout, which lead to various psychosomatic disorders with temporary or permanent limitations on suitability for work at sea ${ }^{14,15}$.

That means that any non-standard psycho-emotional load in the emergency situation during work at sea can render unfavorable stressful tension, individual reaction to which, changing in a wide enough range of values, depends on the type of higher nervous activity, methods of vegetative response, reflects the psychophysiological status of a seafarer's body and his operational reserves.

In the work a number of emergency situations at sea caused by ship operator's errors are analyzed taking into account a number of psychophysiological parameters. Thus, it is shown that in $47 \%$ of cases the accident was caused by the errors of analyzers; in $21 \%$ - due to failures in storage and processing of information; in $18 \%$ - due to failures in decisionmaking, and in $14 \%$ - due to motor errors caused by the performance of the operator $^{16}$.

In the work results of psychophysiological researches are shown among senior students of a shipbuilding specialty and navigators at their retraining on radar simulator. A number of psychophysiological indicators have been studied in order to determine the possibility of their use to assess the level of formation of production dynamic stereotype in mastering the skill of ship navigation maneuvering. Sensomotor reactions, attention tests, operative memory, thinking, strength and mobility of nervous processes were analyzed. However, the quality of mnemonic processes was not sufficiently studied by the authors ${ }^{17}$.

In the work questions of influence of a functional condition and psychophysiological characteristics on the operator, his ability to work in a

14 Rymina T. N., Pyatyrova Ye. V. (2014) Osobennosti vozdeystviya stressa na rabotnikov plavsostava $\mathrm{v}$ usloviyakh raboty $\mathrm{v}$ more [Features of the effects of stress on crew members in working conditions at sea]. Zdorovye. Meditsinskaya ekologiya. Nauka. vol. 4(58), pp. 103-105.

${ }^{15}$ Metodichní vkazívki MV 7.7.4.09302 (2002) Psikhofíziologichniy profesiyniy vidbir plavskladu vodnogo transportu [Psychophysiological proffessional viddir floating warehouse water trans-port. Methodical instructions]. Kiev: ministerstvo okhoronyzdorovya (in Ukrainian).

${ }^{16}$ Vilsky G. B., Maltsev A. S., Bezdolny V. V., Goncharov E. I. (2007) Navigatsionnaya bezopasnost pri lotsmanskoy provodke sudov [Navigation safety during pilotage of ships]; pod red. A. S. Maltseva, G. B. Vilskogo. Odessa-Nikolayev: Feniks (in Ukrainian).

${ }^{17}$ Maltsev A. S., Golikova V. V. (2007) Dinamika psikhofiziologicheskikh funktsiy u kursantov i sudovoditeley pri reshenii zadach sudovozhdeniya na radiolokatsionnom trenazhere [Dynamics of psychophysiological functions among cadets and navigators in solving navigation problems on a radar simulator]. Aktualnyye problemy transportnoy meditsiny : sb. nauchn. trudov, Odessa : UkrNII meditsiny transporta. Vol. 1 (7), p. 20-26 (in Ukrainian). 
bridge team, at influence of ship environment and external influences are considered. It has been shown that working in an emergency situation requires the master to perform both the operator's functions of the ship control and operational functions of human management, with a severe shortage of time that remains throughout the course of the emergency. However, the list of all possible emergency conditions is insufficiently considered, and there is no development of a method of forming a steady skill of work of the bridge ship crew in conditions of emergency at sea ${ }^{18}$.

Analysis of adverse production factors among sailors allowed them to be systematized as follows: the effect of general vibration, noise arising from a working propeller shaft, technological equipment of the vessel and transmitted through the metal bulkheads and vessel structures to the premises regardless of the purpose of production or residential throughout the voyage; exposure to adverse weather factors (humidity, temperature, wind speed); insufficient artificial light and lack of natural light in industrial premises; physical activity (during reloading operations - lifting and moving weights over $30 \mathrm{~kg}$ ), staying in a working position while standing more than $80 \%$ of the time of a work shift; mental stress - work in time-constrained situations when eliminating emergencies, the degree of responsibility for the safety of others, the degree of risk to one's own life, the degree of responsibility for the result of one's own activity, the intelligibility of words in an industrial setting less than $50 \%$, the solution of complex tasks with a choice of a series of instructions, processing, verification and monitoring of the assignment, shift with night work, 12 hours, working hours, lack of regulated breaks, psycho-emotional stress - a long stay in a confined space of the vessel, on the orders of the captain participation in non-specific core activities, limited information on certain circumstances of professional activity, high dynamics, or, conversely, monotonous labor activity, etc.; violation of biological rhythms is of great medical and social importance; as a result of the ratio of supply and demand, labor requirements - frequent transfers of workers from one vessel to other vessels within the same shipping company.

Another getting used to a new job, establishing relationships with new people, etc. also leads to nervous and psychological stress ${ }^{19}$.

18 Mosyagin I. G., Khugayeva S. G., Boyko I. M. (2013) Psikhofiziologicheskiye strategii adaptivnogo professiogeneza moryakov tralovogo flota v usloviyakh Arkticheskogo Severa: monografiya [Psychophysiological strategies of adaptive occupational genesis of trawl fleet sailors in the Arctic North: monograph]. Arkhangelsk: Izd-vo Severnogo gosudarstvennogo meditsinskogo universiteta (in Russian).

19 Topalov V. P., Torskiy V. G. (2015) Chelovecheskiy faktor v sudokhodstve [The human factor in shipping]. Odessa : Astroprint (in Ukrainian). 
This means that the work of the crew under the influence of the factors of the marine environment causes a significant stress in the body of all adaptive systems with a possible violation of the functional state of the main regulatory systems, leading to a deterioration in health and a decrease in working capacity.

As it follows from the work, the attempt to reduce the influence of the man himself on the control process by automating the performance of individual functions does not exclude him from the sphere of control, but leads to even closer communication with devices and systems ${ }^{20}$.

The man-operator (MO) began to operate according to the readings of devices and indicators, and it increases requirements to his psychophysiological functions: memory, thinking, speed of intellectual actions.

According to [16], the quality of the main visual (receptor-eye) and hearing (receptor-ear) analysers determines the specific nature of the ship's motion control process. Thus, up to $90 \%$ of the information is visual, the second place is occupied by the use of a hearing analyzer and speech, other analyzers account for a small part of the information ${ }^{21}$.

Therefore, in the operator's activity, errors occur in the process of obtaining visual information and its analysis, based on previous experience, due to the professional skills of training, increasing the time of its processing, and the stage of control failure is characterized by the loss of orientation. Also, delays in the intellectual activity of the operator affect the speed and reliability of production decision-making and control over its implementation.

Thus, formation of qualitatively new professional skills on the basis of psychophysiological factor of memory is necessary for a seafarer, especially in difficult modern conditions of navigation.

\section{THE ROLE OF MEMORY IN THE MECHANISM OF FORMATION OF QUALITATIVELY NEW PROFESSIONAL SKILLS OF A NAVIGATOR}

The seafarer's job requires the necessary personal characteristics to ensure that the duties are performed in the best possible way, taking into account unusual situations. Assessment and prediction of the implementation of such

${ }^{20}$ Leontyev V. A. (1987) Formirovaniye professionalnykh navykov sudovoditeley [Formation of professional skills of navigators]. Moscow: Transport (in Russian).

${ }^{21}$ Maltsev A. S., Golikova V. V. (2007) Dinamika psikhofiziologicheskikh funktsiy u kursantov i sudovoditeley pri reshenii zadach sudovozhdeniya na radiolokatsionnom trenazhere [Dynamics of psychophysiological functions among cadets and navigators in solving navigation problems on a radar simulator]. Aktualnyye problemy transportnoy meditsiny : sb. nauchn. trudov, Odessa : UkrNII meditsiny transporta. Vol. 1 (7), p. 20-26 (in Ukrainian). 
properties is very important for each particular seafarer of a ship crew on a long voyage, against the background of accumulated fatigue, and even more so in emergency and extreme circumstances.

In order to assess the efficiency of the ship crew members to react optimally in "danger" conditions when working at sea, the following properties of the functional state are taken into account: 1) short-term memory (for the period of performance of one task, operation); 2) concentration of attention (high concentration on performance of one task, without distractions); 3 ) operational intelligence (ability to quickly analyze a problem, to compare with an operational task and make the decision); 4) monotonous activity (concentration, stability and efficiency of performing monotonous activity for a long time); 5) anxiety (periodic filling of the mental space with restless, tense thoughts, distracting from the operational activity); 6. aggression (excessive negative reaction to external stimuli, high readiness for irritation); 7) fatigue (rapid decrease in efficiency); 8) oppression (prevalence of gloomy, pessimistic thoughts); 9) activity (need for activity above the norms); 10) optimism (meaning actual emotional mood, not philosophical or political position); 11) sleep (shallow, intermittent, not giving full rest); 12) appetite (indifference to food, up to rejection in thoughts); 13) efficiency in terms of speed (working fast in a limited period of time); 14) efficiency in terms of time (working fast and for a long time) ${ }^{22}$.

The ship's crew depends on the quality of the ship's manager potential, his temperamental and temporal characteristics, which largely determine the level of responsibility, behavioral success, optimal pace of activity, the safety margin of his body from stress.

Therefore, in seamanship, there is the principle of the formation of modern shipboard specialists of two opposite qualities that they should possess in connection with the dynamics of changes in public life. This, on the one hand, has a stable solid core, worldview, social and moral convictions, and on the other hand, has high psychological lability, the ability to absorb and process new information and create something new throughout your life ${ }^{23}$.

In the last decade, the understanding of the role of the human factor in the professional activities of seafarers has changed: interest in studying the needs of a modern ship specialist as a professional, his value ideas, and social and

22 Mosyagin I. G., Khugayeva S. G., Boyko I. M. (2013) Psikhofiziologicheskiye strategii adaptivnogo professiogeneza moryakov tralovogo flota v usloviyakh Arkticheskogo Severa: monografiya [Psychophysiological strategies of adaptive occupational genesis of trawl fleet sailors in the Arctic North: monograph]. Arkhangelsk: Izd-vo Severnogo gosudarstvennogo meditsinskogo universiteta (in Russian).

${ }^{23}$ Leontyev V. A. (1987) Formirovaniye professionalnykh navykov sudovoditeley [Formation of professional skills of navigators]. Moscow: Transport (in Russian). 
normative attitudes has sharply increased. However, the existing factors of the seafarers' working conditions are limited to work in a confined space, sensory deprivation, increased responsibility, strict regulation of the watch cyclogram of activity, the same landscape, limited ability to satisfy cultural needs and communication, sexual maladaptation, prolonged emotional stress, the need for normal social conditions for living, extreme factors of working conditions, psychosocial disorders ${ }^{24}$.

These factors are especially significant for extroverts, who are less likely to tolerate prolonged psychosensory isolation due to their tendency to excessive emotional contact, the need for constant communication.

For introverts and extroverts, prolonged psycho-traumatic situations can in some cases lead to significant changes in the emotional state, to professional burnout, to the indifference of performing one's professional duties. According to professional examinations, shipboard specialists, who are characterized by increased anxiety, try to avoid responsible tasks, and if necessary, solving super-responsible tasks can fall into a state close to panic. Personal anxiety in these cases becomes extremely high and, as a result, provokes high situational anxiety, which can cause an incorrect response to the situation.

So, it was found that among captains over 56 years of experience with more than 17 years of experience, $84 \%$ have a low level of neurotism, psychotism and moderate personal anxiety, which indicates a high mental stability, emotional lability and the least susceptibility to nervous breakdowns. However, $16 \%$ of captains have a high level of neurotism, psychotism and personal anxiety, which may be accompanied by a tendency to antisocial behavior, the use of alcohol, drugs, increased conflict and irritability. This means that this category of marine specialists should be considered as a "risk" group in management activities and recommend regular psychological support (individual psychological counseling, psychological training, self-regulation of behavior, etc.) after the end of each voyage. Otherwise, an unfavorable forecast is expected in the event of a difficult production situation on the ship. This is primarily due to the fact that the properties of temperament and personal anxiety are some of the factors of professional activity ${ }^{25,26}$.

${ }^{24}$ Matseyevich L. M. (1986) Okhrana zdorovya moryakov [Health protection of sailors]. Moscow: Transport (in Russian).

${ }^{25}$ Panov B.V., Balaban S.V., Cheban S. G., Samys'ko D. B., Lisobey V. A. (2013) Sostoyaniye zdorov'ya moryakov po rezul'tatam predvaritelnykh i periodicheskikh osmotrov. Soobshcheniye pervoye: mediko-statisticheskaya kharakteristika moryakov [The health status of seafarers according to the results of preliminary and periodic examinations. First message: medical and statistical characteristics of sailors]. Aktual'nyye problemy transportnoy meditsiny, no. 3(33), pp. 66-73. 
During the inter-flight retraining, it is necessary to focus the attention of ship specialists on the existing problem, to help realize that experience does not protect against errors in professional activity, and the reliability of a person has limits and is due to personality traits and some age-related changes.

High anxiety can cause an incorrect response to the current situation on the ship. Low anxiety indicates indifference, indifference and unpreparedness to solve professional problems. Therefore, in this "risk" group, the reliability of professional activity will be significantly lower than that of colleagues who are enrolled in the "prospective" category, work as captains and have a moderate level of anxiety.

The "risk" group also includes specialists who, in adulthood, underwent professional retraining in another specialty, which makes it possible to continue working at sea. For example, radio operators "retrained" as boatmasters. If earlier they were high-class specialists, then the professional experience in the newly acquired profession is now much lower. There is a mismatch between previous work experience and newly acquired experience, which affects the reliability of professional activities. There will also be a higher level of anxiety, which is due to the situation of a change in professional activity, which reduces its productivity ${ }^{27}$.

Stresses have a negative effect on both psychophysiological parameters, which include attention, perception, reproduction, consciousness, thinking, which make up the intellect, and which are based on both the memory factor and physical health.

A high assessment of the working capacity of the command staff on the vessel indicates excellent memory, attention, steady, error-free operation in conditions of monotony and fatigue, as well as in conditions of severe psychoemotional stress in the event of a danger ${ }^{28}$.

${ }^{26}$ Panov B.V., Balaban S.V., Cheban S. G., Samys'ko D. B., Lisobey V. A. (2013) Sostoyaniye zdorov'ya moryakov po rezul'tatam predvaritel'nykh i periodicheskikh osmotrov. Soobshcheniye vtoroye: pokazateli zabolevayemosti moryakov raznykh vozrastnykh i stazhevykh grupp [The health status of seafarers according to the results of preliminary and periodic examinations. Second communication: morbidity indicators for sailors of different age and senior groups]. Aktualnyye problemy transportnoy meditsiny. no 3 (34), pp. 47-56 (in Ukrainian).

27 Rymina T. N., Pyatyrova Ye. V. (2014) Osobennosti vozdeystviya stressa na rabotnikov plavsostava $\mathrm{v}$ usloviyakh raboty $\mathrm{v}$ more [Features of the effects of stress on crew members in working conditions at sea]. Zdorovye. Meditsinskaya ekologiya. Nauka. vol. 4(58), pp. 103-105.

${ }^{28}$ Kolegaev M. A., Ivanov B. N., Basanets N. G. (2007) Bezopasnost zhiznedeyatelnosti i vyzhivaniye na more: Ucheb posobiye [Life Safety and Survival at Sea: Textbook]. Pod red. V. V. Ponomarenko. Odessa : ONMA (in Ukrainian). 
Stresses have a negative impact on both the psychophysiological parameters, which include attention, perception, reproduction, consciousness, thinking, the components of intelligence, and which are based on both memory and physical health.

The high estimation of efficiency of the command crew on the vessel shows excellent memory, attention, stable, error-free work in the conditions of monotony and fatigue, as well as in conditions of severe psycho-emotional stress in case of danger.

Memory is a set of psychophysiological processes that allow us to capture, store and reproduce past experiences.

The organization levels of the psyche as a system are arranged in a step-bystep hierarchy row, with each stage characterized by its own functional subsystem, resulting from the interaction of one or another stage. Therefore, memory can be considered as a subsystem of psyche in which short-term memory can be considered as a level of hierarchy or a subsystem of memory, and the long-term memory as another subsystem of memory. A specific feature of any hierarchical organization is the association of various components of biological levels into new functional units, which lead to the formation of qualitatively new, emergent properties of such units ${ }^{29}$.

Memory is the fixation, preservation and subsequent replication by a person of his or her experience, where the physiological basis of memory is a conditional reflex as an act of forming a temporal connection between stimulus and reaction. Therefore, human memory functions on psychological, physiological and molecular chemical levels, and ribonucleic acid (RNA) is the basis of individual memory. Changes in the RNA structure are related to long-term memory. Shortterm memory is generated when information transmitted by receptors has caught the brain's attention and can be stored for a short period of time, and during this period the brain processes and interprets this information.

Moreover, short-term memory is characterized not only by certain duration of information holding but also by capacity, i.e. the ability to store a certain number of dissimilar information elements simultaneously. The long-term memory itself is composed of several elements that the brain selects. This is what will be stored in memory for a long time. The capacity and duration of long-term memory is unlimited, depending on how important the information to be memorized is to the person, as well as how it is encoded, arranged, and reproduced.

${ }^{29}$ Albekov N. N., Albekov N. N. (2015) Emerdzhentnost kak obyekt sovremennoy nauki [Emergence as an object of modern science]. Sovremennyye problemy nauki i obrazovaniya, no. 2-1. URL: http://science-education.ru/ ru/article/view?id=21089 
Thus, the mechanism of memory shaping is based on conditional reflexes the stable connection between a random signal and the unconditional reflex arising as a result of repeated coincidence as one of the types of associative learning.

However, there is a significant area of acquired behaviour that is shaped by other mechanisms, such as operant conditioning. Operant conditioning can be regarded as a type of combined reflexes when there is a stable connection between a certain type of behavior and its consequences, namely, its positive or negative backing.

Therefore, such a psychophysiological parameter as memory acquires new features or qualities considering the principle of emergence, i.e. it acquires emergence properties, which also allows studying the very behavior of a person: for example, under what conditions a certain task will be better performed, for example, to develop a particular professional skill.

Such qualitatively new, emergent, properties of the psychophysiological factor of memory cannot be predicted, proceeding from properties of the single components making this level and, there is a possibility to expand considerably the volume of the memory: possibility to allocate essential on a background of the inserted, actively to reproduce the necessary material, widely using mnemonic receptions ${ }^{30}$. Memory features as a psychological process have such formation as association or temporary nervous connection. By means of associations on adjacency the person learns different kinds of activity, a verbal material.

A man intentionally, at his own discretion, remembers and reproduces something, that is, directs his activity to achieve the set goal. Remembering is always selective. Not everything that affects our senses is memorized, but only what a person acts with.

The main methods of memorization are: a) breakdown of the material into constituent parts; b) creation of titles or a reference point with which all the content of a certain part of the material is associated; c) linking the parts by their titles into a single chain of associations.

Preserving and forgetting are two interrelated processes. These processes determine what will remain in our memory. Preserving is the process of keeping what we learn in our memory. From a physiological point of view, it is the maintenance of previously established connections in the brain through reinforcement.

${ }^{30}$ Albekov N. N., Albekov N. N. (2015) Emerdzhentnost kak obyekt sovremennoy nauki [Emergence as an object of modern science]. Sovremennyye problemy nauki i obrazovaniya, no. 2-1. URL: http://science-education.ru/ ru/article/view?id=21089 
A number of factors help to preserve information: depth of understanding; attitude (value of information); application of learned knowledge; repetition (degree of material utilization in the activity).

\section{THE ROLE OF EMERGENT MEMORY PROPERTIES} IN IMPROVING CREW COMPETENCE AND NAVIGATION SAFETY

The profession of people working in the water transport, in its difficult working conditions, is significantly different from all other professions, since a long time ago a large number of various unfavorable factors also affect human health. These include: natural factors, the rapid change of climatic and geographical zones and time zones, the shift regime of work and rest, the specifics of food and water supply on ships. Adverse factors also include: a long separation from the family, forced stay in a limited space with a permanent team, as well as adverse factors: noise, vibration, electromagnetic fields, frequent changes in climatic zones and others.

All this causes a restructuring of many functional systems of the human body, when adaptation is achieved at a high price and is often accompanied by the development of stress, which is not always short-lived ${ }^{31}$.

The crew labor under the influence of ship environment factors causes considerable tension of all adaptation systems in the body with possible violation of the functional state of the main regulatory systems, leading to the development of emotional-stress situation, rapid worsening of health condition, to the decrease of working capacity, which leads to the impossibility of making optimal decisions in case of unfavorable working situation at sea or hazards resulting in direct threat both to the ship and crew members.

In difficult conditions of work at sea, the information component of work with high nervous and emotional stress, which requires a large concentration and mobilization of psychophysiological reserves and adaptive capacity of the body, becomes the leading one.

According to scientists, analysis of ship accidents confirms the leading role of the "human factor" in statistics of accidents. The attempt to reduce influence of the person at the expense of automation of separate functions performance does not exclude it from a control sphere, and leads to even closer communication with devices and systems ${ }^{32}$.

${ }^{31}$ Kubasov R. V., Lupachev V. V., Popov M. V. (2016) Usloviya zhiznedeyatel'nosti ekipazha na bortu morskogo sudna (obzor literatury) [Conditions of crew life aboard a marine vessel (literature review)]. Vestnik Gosudarstvennogo universiteta morskogo $i$ rechnogo flota imeni admirala S. O. Makarova, no. 2(36), pp. 49-56.

${ }^{32}$ Topalov V. P., Torskiy V. G. (2015) Chelovecheskiy faktor v sudokhodstve [The human factor in shipping]. Odessa : Astroprint (in Ukrainian). 
Vascular and autonomic changes in an operator's body that accompany his professional activity correlate mainly with his emotional state, which is determined by the level of use of knowledge and skills in the process of realization of intellectual actions, i.e. the level of skill and memory. The success of intellectual functions of an operator's activity largely depends on the skill level of the operator, the state of psychophysiological functions in the body, and their consistency with movement factors.

The formation of a functional system of individual type of stable professional operator activity is clearly shown in the dynamics of psychophysiological functions. Their combination represents a number of typical psychophysiological conditions reflecting the skill level and rationally used psychophysiological functions ${ }^{33}$.

The levels of any structure or system are arranged in a step-by-step hierarchy raw, with each level characterized by its own functional subsystem resulting from the interaction of a particular level with the physical environment.

A peculiar feature of the hierarchical structure is that the unification of different components of biological levels into new functional units leads to the creation of qualitatively new, emergent properties of such units. New units, appearing at unification of different components, show properties, which were absent at the previous level.

The concept of emergence is widely used today in various sciences, defining qualitatively new properties peculiar to emergence specifically in a certain system $^{34}$. The peculiarity of emergence is its indivisibility, unpredictability, novelty, inexplicability, as well as the reflecting of the essence of something greater and global. The more complex and multi-component is the structure of the system, the more extensive are the essential properties of emergence. The more complex and multi-component the structure of a system, the more logical it is from the point of view of its emergent properties. Emergent properties can be expressed through the concept of irreducible properties, meaning that the properties of the whole cannot be represented as a sum of properties of its components. This principle of irreducibility of the properties of the whole to the

${ }^{33}$ Maltsev A. S., Golikova V. V. (2007) Dinamika psikhofiziologicheskikh funktsiy u kursantov i sudovoditeley pri reshenii zadach sudovozhdeniya na radiolokatsionnom trenazhere [Dynamics of psychophysiological functions among cadets and navigators in solving navigation problems on a radar simulator]. Aktualnyye problemy transportnoy meditsiny : sb. nauchn. trudov, Odessa: UkrNII meditsiny transporta. Vol. 1 (7), p. 20-26 (in Ukrainian).

${ }^{34}$ Albekov N. N., Albekov N. N. (2015) Emerdzhentnost kak obyekt sovremennoy nauki [Emergence as an object of modern science]. Sovremennyye problemy nauki i obrazovaniya, no. 2-1. URL: http://science-education.ru/ ru/article/view?id=21089 
sum of the properties of its components - the emergence principle - serves as one of the basic principles for the study of mental parameters, in particular such a psychophysiological factor as memory. By means of the emergence phenomenon one can productively interpret and study the phenomena of complex systems (which can include most of the phenomena with which the modern man interact, and the man himself as well), which cannot be explained by narrowing down to the basic components.

There is a significant area of acquired behaviour that is shaped by other mechanisms. In contrast to the conditional reflex, in which the appearance of a reaction to a conditional signal is always preceded by its amplification, a reaction that has been amplified in the past may be formed: not as a signal of what will happen, but as an amplification of what has already been done. This mechanism represents an operant conditioning, which can be regarded as a kind of combined reflexes, and the appearance of a stable connection between a certain type of behavior and its consequences, namely, its positive or negative amplification. In operant conditioning, behavior itself is studied: for example, under what conditions a certain task will be better performed.

The mechanism of association is to establish a connection between the impressions that simultaneously arise in consciousness, and its reproduction by the individual.

The basic principles for creating associations between objects are: the coincidence of their influence in space and time, similarity, contrast, as well as their repetition by the subject. Human memory is represented by three types of associations: verbal (links between words), external (links between objects), internal (logical connectives of meanings). Verbal associations are considered as the most important means of internalizing sensory impressions, so that they become objects of memorization and reproduction.

According to the associative theory, individual elements of information are remembered, stored and reproduced not in isolation, but in certain logical, structural, functional and semantic relationships with others.

The number of elements that are memorized depends on the frequency of their repetition, the elements of the sequence of memorized elements themselves and the duration in time, and especially they depend on the time elapsed between memorization and reproduction.

Memory also depends on the morphological and functional features of the material being memorized. For example, poorly structured material is very difficult to remember, while well-organized material is easy to remember and almost without repetition. When the material does not have a clear structure, the individual often divides or combines it through rhythmization, symmetrization. Man himself seeks to rebuild the material so that he can better remember it. 
But not only the organization of the material determines the effectiveness of memory. Memory is a set of processes that allow you to capture, store and reproduce past experience, therefore, there are clear relationships between the objective structure of the material, the activity of the individual and the performance of memory.

One of the emergence forms is the principle of transition of certain quantitative changes of functional units to other qualitative ones, causing the integrity of the structure or system, as these units or components or subsets are combined into larger functional units, these new units have new qualitative properties that were absent at the previous hierarchical level.

Consequently, such qualitatively new emergent properties of the psychophysiological memory factor cannot be predicted based on the properties of single components that make up this level. Emergent properties arise as a result of the interaction of the components, not as a result of changes in the nature of these components. These parts are integrated, resulting in unique new emergent properties.

The habit of remembering the right is fixed, like any other skill.

Simon (1973) showed mathematically that integrated hierarchical systems arise more quickly from their component parts than non-hierarchical systems having the same number of elements; they are also more plastic in relation to violations ${ }^{35}$.

Theoretically, if a hierarchical system is decomposed into subsystems of different levels, then the latter can continue to interact and are organized again, reaching a higher level of complexity (Laszlo, 1972).

Since homeostatic mechanisms function at all levels, namely, corrective and balancing processes, acting and counteracting forces, the amplitude of oscillations tends to decrease when we move on to the consideration of smaller units functioning inside large ones.

Statistically the scatter of integer values is less than the sum of the scatter of parts. If we take into account the emergent properties and enhancement of homeostasis at each level, then, to study the whole, it is not necessary to know all its components. The study can be started from anywhere in the spectrum, provided that not only the studied, but also neighboring levels are taken into account, since some properties of the whole can be predicted based on the properties of its parts (aggregate properties), while others cannot (emergent properties).

${ }^{35}$ Albekov N. N., Albekov N. N. (2015) Emerdzhentnost kak obyekt sovremennoy nauki [Emergence as an object of modern science]. Sovremennyye problemy nauki i obrazovaniya, no. 2-1. URL: http://science-education.ru/ ru/article/view?id=21089 
According to Patten (1978), an ideal study of any level of the system includes the study of a three-membered hierarchy: systems, subsystems (neighboring lower level) and supersystem (next upper level).

Each level of a biosystem is characterized by its own properties inherent only to it, and in addition, it has the sum of the properties of its subsystemcomponents $^{36}$.

The principles of emergence can also be applied to the educational process, which becomes relevant in context of global digitalization.

The authors based on the analysis of modern mixed forms of education, the development of distance learning, the need for the use of information and communication technologies, the development of electronic educational resources, introduced the concept of "emergent education". Emergent learning is understood as a form of organization and management of educational activities in a systematic approach, together with the use of information and communication technologies, e-learning and traditional contact teaching in the classroom $^{37}$.

Moreover, the result of training and the quality of the success of education will always depend on the motivation of the subject.

Thus, the given qualitatively new, emergent properties of the psychophysiological factor of memory cannot be predicted, proceeding from properties of the single components constituting this level, it shows that there is a possibility to expand considerably the memory volume: the ability to highlight the essential against the background of the secondary, actively reproduce the necessary material, widely using mnemonic techniques.

Consequently, the main tasks to be performed in the training of a seafarer are the formation of initial, sustainable, and restoring sustainable skills, practising them until they become automatic based on the emergent memory property.

Such research data can serve for further developments in the formation of qualitatively new professional skills based on the psychophysiological factor of memory necessary for a seafarer, especially in difficult modern conditions of navigation.

${ }^{36}$ Albekov N. N., Albekov N. N. (2015) Emerdzhentnost kak obyekt sovremennoy nauki [Emergence as an object of modern science]. Sovremennyye problemy nauki i obrazovaniya, no. 2-1. URL: http://science-education.ru/ ru/article/view?id=21089

${ }^{37}$ Doug Blank, Kim Cassidy, Anne Dalke, Paul Grobstein (2019) Emergent Pedagogy: Learning to Enjoy the Uncontrollable and Make it Productive. URL: http://serendip.brynmawr.edu/sci_edu/emergentpedagogy.html 


\section{CONCLUSIONS}

The analysis of literature sources has shown that the development of modern marine technology goes in the direction of increasing use of high-speed intelligent technologies, the introduction of integrated systems for automatic control of ship processes.

It is shown that in conditions of work at sea, the information component of work with high nervous and emotional tension, demanding the big concentration of attention and responsibility, mobilization of psychophysiological reserves, adaptive possibilities of a body, ability to find the correct decision in time shortage of difficult, sometimes extreme situations based on the acquired skills and knowledge of the expert, or formation of qualitatively new emergent properties of memory becomes the leading one. The connection between the psychophysiological parameter, memory and the notion of emergence with the purpose of substantiation of its emergent properties as the basic mechanism of formation of qualitatively new professional skills in a ship-builder has been analyzed.

Possibility to acquire emergent properties of memory on the basis of development of conditional reflexes and automatic behavior for the purpose of increasing crew proficiency and, consequently, navigation safety has been revealed.

It is grounded that the research relevance is conditioned both by the practice request and by the need to solve the main issues that should be solved during the seafarer's training - it is the formation of the initial, sustainable, and restoration of sustainable, with bringing it to automatism, professional skills, because the safety of modern navigation depends on the level of training of the command squad.

Thus, such qualitatively new, emergent properties of the psychophysiological memory factor cannot be predicted, based on the properties of single components that make up this level, it is possible to significantly expand the volume of memory: to allocate the essential against the background of the secondary, actively reproduce the necessary material, widely using mnemonic techniques.

These researches can serve for further development of the study in formation of qualitatively new professional skills on the basis of memory necessary for a seafarer, especially in difficult modern conditions of navigation.

\section{SUMMARY}

The article analyzes the literature data, which showed that the development of modern maritime technology is moving towards the wider application of high-speed intelligent technologies, the introduction of integrated systems for the automatic control of ship processes. 
It is shown that under working conditions at sea, the information component of labor with high neuro-emotional stress, which requires a high concentration of attention and responsibility, mobilization of psychophysiological reserves, adaptive capabilities of the body, the ability to find the right solution in a temporary shortage of complex, and sometimes extreme situations, becomes the leading based on acquired skills and knowledge of a specialist, and the formation of qualitatively new emergent properties of memory.

The relationship between the psychophysiological parameter memory and the concept of emergence is analyzed in order to justify its emergent properties as the main mechanism for the formation of qualitatively new professional skills for the skipper. Memory is a combination of a number of specific psychophysiological processes that allow you to capture, store and reproduce past experience, in particular, the processes of professional learning.

The possibility of acquiring the emergent properties of memory on the basis of the development of conditioned reflexes and automatisms of working skills with the aim of increasing the professionalism of the crew and, therefore, the safety of navigation is revealed.

It is substantiated that the relevance of the study is due to both the request for practice and the need to solve the main tasks that should be solved when preparing the sailor - this is the formation of the crew of the initial, stable, and restoration of the stable, bringing it to the automatism of professional skills, because, from the level of training of the crew of the ship, the safety of modern navigation depends.

Thus, such qualitatively new, emergent, properties of the psychophysiological memory factor cannot be predicted on the basis of the properties of the individual components that make up this level, and it is possible to significantly expand the volume of one's memory: to highlight the essential against the background, actively reproduce the necessary material, widely using mnemonic techniques.

These studies can serve for further developments in the study in the formation of qualitatively new professional skills on the basis of the psychophysiological memory factor necessary for a sailor, especially in difficult modern conditions of navigation.

\section{REFERENCES}

1. Nikitina V. N., Lyashko G. G., Kalinina N. I. (2016) Osobennosti professionalnoy deyatelnosti moryakov na avtomatizirovannykh sudakh i zdorovye ekipazha [Features of the professional activities of sailors on automated vessels and crew health]. Profilakticheskaya meditsina: materialy 
Vserossiyskoy nauchno-prakticheskoy konferentsii $s$ mezhdunarodnym uchastiyem (Russia, St. Petersburg, Noyabrya 15-16, 2016) (eds. A. V. Meltsera, I. Sh. Yakubovoy). SPb.: Izd-vo SZGMU im. I. I. Mechnikova, vol. 2, pp. 88-93 (in Russian).

2. Zelenin M. P. (1999) Ergonomika na morskom transporte [Ergonomics in maritime transport], Odessa: BANTO (in Ukrainian).

3. Maltsev A. S., Golikova V. V. (2007) Dinamika psikhofiziologicheskikh funktsiy u kursantov i sudovoditeley pri reshenii zadach sudovozhdeniya na radiolokatsionnom trenazhere [Dynamics of psychophysiological functions among cadets and navigators in solving navigation problems on a radar simulator]. Aktualnyye problemy transportnoy meditsiny : sb. nauchn. trudov, Odessa: UkrNII meditsiny transporta. Vol. 1 (7), p. 20-26 (in Ukrainian).

4. Kubasov R. V., Lupachev V. V., Popov M. V. (2016) Usloviya zhiznedeyatel'nosti ekipazha na bortu morskogo sudna (obzor literatury) [Conditions of crew life aboard a marine vessel (literature review)]. Vestnik Gosudarstvennogo universiteta morskogo $i$ rechnogo flota imeni admirala S. O. Makarova, no. 2(36), pp. 49-56.

5. Kolegaev M. A., Ivanov B. N., Basanets N. G. (2007) Bezopasnost zhiznedeyatelnosti i vyzhivaniye na more: Ucheb posobiye [Life Safety and Survival at Sea: Textbook]. Pod red. V. V. Ponomarenko. Odessa: ONMA (in Ukrainian).

6. Rymina T. N., Pyatyrova Ye. V. (2014) Osobennosti vozdeystviya stressa na rabotnikov plavsostava $\mathrm{v}$ usloviyakh raboty $\mathrm{v}$ more [Features of the effects of stress on crew members in working conditions at sea]. Zdorovye. Meditsinskaya ekologiya. Nauka. vol. 4(58), pp. 103-105.

7. Vagushchenko L. L., Tsymbal N. N. (2002) Sistemy avtomaticheskogo upravleniya dvizheniyem sudna [Systems of automatic control of the movement of the vessel]. Odessa: Latstar (in Ukrainian).

8. Mamayenko Yu.V., Chernenko Ye. V. (2010) Psikhofiziologicheskiye korrelyaty professionalnoy adaptatsii moryakov [Psychophysiological correlates of professional adaptation of sailors]. Aktualnyye problemy transportnoy meditsiny, no. 1 (19), pp. 31-36.

9. Panov B. V., Balaban S. V., Cheban S. G., Samys'ko D. B., Lisobey V. A. (2013) Sostoyaniye zdorov'ya moryakov po rezul'tatam predvaritelnykh i periodicheskikh osmotrov. Soobshcheniye pervoye: medikostatisticheskaya kharakteristika moryakov [The health status of seafarers according to the results of preliminary and periodic examinations. First message: medical and statistical characteristics of sailors]. Aktual'nyye problemy transportnoy meditsiny, no. 3(33), pp. 66-73. 
10. Panov B. V., Balaban S. V., Cheban S. G., Samys'ko D. B., Lisobey V. A. (2013) Sostoyaniye zdorov'ya moryakov po rezul'tatam predvaritel'nykh i periodicheskikh osmotrov. Soobshcheniye vtoroye: pokazateli zabolevayemosti moryakov raznykh vozrastnykh i stazhevykh grupp [The health status of seafarers according to the results of preliminary and periodic examinations. Second communication: morbidity indicators for sailors of different age and senior groups]. Aktualnyye problemy transportnoy meditsiny. no 3 (34), pp.47-56 (in Ukrainian).

11. Metodichní vkazívki MV 7.7.4.09302 (2002) Psikhofíziologichniy profesiyniy vidbir plavskladu vodnogo transportu [Psychophysiological proffessional viddir floating warehouse water trans-port. Methodical instructions]. Kiev: ministerstvo okhoronyzdorovya (in Ukrainian).

12. Vilsky G. B., Maltsev A. S., Bezdolny V. V., Goncharov E. I. (2007) Navigatsionnaya bezopasnost pri lotsmanskoy provodke sudov [Navigation safety during pilotage of ships]; pod red. A. S. Maltseva, G. B. Vilskogo. Odessa-Nikolayev: Feniks (in Ukrainian).

13. Mosyagin I. G., Khugayeva S. G., Boyko I. M. (2013) Psikhofiziologicheskiye strategii adaptivnogo professiogeneza moryakov tralovogo flota $\mathrm{v}$ usloviyakh Arkticheskogo Severa: monografiya [Psychophysiological strategies of adaptive occupational genesis of trawl fleet sailors in the Arctic North: monograph]. Arkhangelsk: Izd-vo Severnogo gosudarstvennogo meditsinskogo universiteta (in Russian).

14. Topalov V. P., Torskiy V. G. (2015) Chelovecheskiy faktor v sudokhodstve [The human factor in shipping]. Odessa: Astroprint (in Ukrainian).

15. Leontyev V. A. (1987) Formirovaniye professionalnykh navykov sudovoditeley [Formation of professional skills of navigators]. Moscow: Transport (in Russian).

16. Matseyevich L. M. (1986) Okhrana zdorovya moryakov [Health protection of sailors]. Moscow: Transport (in Russian).

17. Albekov N. N., Albekov N. N. (2015) Emerdzhentnost kak obyekt sovremennoy nauki [Emergence as an object of modern science]. Sovremennyye problemy nauki $i$ obrazovaniya, no. 2-1. URL: http://science-education.ru/ $\mathrm{ru} /$ article/view $\mathrm{id}=21089$

18. Doug Blank, Kim Cassidy, Anne Dalke, Paul Grobstein.(2019) Emergent Pedagogy: Learning to Enjoy the Uncontrollable and Make it Productive. URL: http://serendip.brynmawr.edu/sci_edu/emergentpedagogy.html 
Information about the authors:

Shevchenko R. P.,

Doctor of Psychology, Associate Professor, Head of the Practical Psychology Department, Odessa National Maritime University

32, Mechnikov str., Odessa, 65007, Ukraine ORCID ID: orcid.org/0000-0003-2515-6717

Researcher ID: AAK-4166-2020

Bondarevich S. M.,

Candidate of Psychological Sciences, Associate Professor at the Practical Psychology Department, Maritime Humanitarian Institute of Training and Research 32, Mechnikov str., Odessa, 65007, Ukraine ORCID ID: orcid.org/0000-0002-7350-2947 